\title{
Driving forces and characteristics of the value chain of flowering potted plants for the German market
}

\author{
N. Havardi-Burger ${ }^{1}$, H. Mempel ${ }^{2}$ and V. Bitsch ${ }^{1}$ \\ ${ }^{1}$ Technical University of Munich, School of Management and School of Life Sciences Weihenstephan, Chair of Economics of \\ Horticulture and Landscaping, Freising, Germany. \\ ${ }^{2}$ University of Applied Sciences Weihenstephan-Triesdorf, Department of Horticulture and Food Technology, Freising, \\ Germany
}

\begin{abstract}
Summary
The study investigated the value chain of flowering potted plants supplying the German market and the drivers influencing chain actors. The study builds on strategic and horticultural value chain literature. Data was collected by conducting 20 in-depth interviews with chain actors from different stages in the value chain and analyzed through qualitative content analysis. Results showed that the value chain of flowering potted plants is divided in two pathways due to distinct propagation methods, either generative (seeds) or vegetative (cuttings). Whereas propagation material is generally produced in southern countries, such as Africa and Central America, young plants and potted plants are cultivated within Europe. The paper identified driving forces such as retailer requirements, weather conditions, price pressure and innovations. Furthermore, the study provides an overview of chain activities and processes to help the sector anticipate developments, and support stakeholders in future decisions.
\end{abstract}

Keywords

certification, chain coordination, floriculture, generative propagation, ornamental plants, qualitative study, retail chains, vegetative propagation

\section{Introduction}

Firms' profitability is determined to a large extent by industry structure and attractiveness. Industry structure also shapes value chains within an industry (Porter, 1985). The value chain describes the range of activities required to bring a product from concept through the different phases of production to delivery to the end consumer (Kaplinsky and Morris, 2000). The value chain, as a concept, was first introduced by Porter (1985) as a framework for thinking strategically about the activities of a business to achieve competitive advantage. Competitive advantage is achieved when a firm earns a higher rate of profit than its rivals. Nevertheless, maintaining competitive advantage depends not only on the firm but on how the firm fits in the value-adding activities of the entire chain. Moreover, the activity-based view provides the foundation for strategy across multiple businesses (Porter, 1985). Within a value chain, such as the horticultural value chain, businesses are dependent on other actors and organized cooperation is required (Bokelmann and Adamseged, 2016). Organized cooperation across businesses is re-

\section{Significance of this study}

What is already known on this subject?

- European studies focused on supply chain management and logistics of floriculture. Value-adding activities and processes of flowering plants supplying the German market have not been investigated.

What are the new findings?

- The value chain is fragmented, but coordination is crucial because of product perishability, and the requirement for on-time delivery. Retail-chains are powerful chain actors through certification requirements and restrictions on pesticide use. NGOs also drive chain actors to take measures to avoid negative media attention. Furthermore, profitability concerns drive actors to strive for cost reduction and increase the consumer base.

What is the expected impact on horticulture?

- An overview of the value chain of flowering plants and its drivers provides a foundation for strategy development and decision making across businesses within the sector.

flected, for example, in the requirement for on-time delivery of plants in the investigated value chain.

Ornamental plants have an important cultural value and contribute to quality of life and well-being (Hall and Hodges, 2011). The German market for ornamental plants is the biggest in Europe from the demand perspective (Menrad and Gabriel, 2009) and was estimated to be worth around 8.9 billion euros (retail prices) in 2019 (AMI, 2020). Potted plants have a market share of $47 \%$, and are distributed via two main channels: (i) specialized retailers (florists, nurseries, garden centers and weekly markets) with 1.8 billion euros in retail prices, and (ii) unspecialized retailers (home improvement stores, supermarket chains and discounters) with 1.9 billion euros in retail prices (AMI, 2019). Flowering potted plants in Germany comprise $33 \%$ of the total market of ornamental plants, and can be divided into bedding plants (21\%) and flowering indoor plants (12\%) (AMI, 2020).

Ornamental plants are not a necessity product like horticultural food crops, and can be considered a luxury. The luxury character of floricultural products makes the sector more susceptible to economic losses during recessions (Brumfield, 2010). Furthermore, the German market shows signs of saturation demonstrated by the stable yearly market value of 
8.6 billion euros on average in the past 15 years (AMI, 2020).

So far, research addressing the floricultural chain has focused on management and logistics in the Netherlands (De Keizer et al., 2015; Van der Vorst et al., 2016), and global value chain analysis in developing countries (Zylberberg, 2013). Value-adding activities and processes in Germany and the Netherlands have not been investigated. However, to understand the economic challenges in the floriculture sector, profound knowledge regarding the value-adding activities in each stage is vital. Furthermore, existing literature focuses mostly on cut flowers, whereas potted plant chains are generally unexplored.

The aim of this study is to identify processes and activities within the value chain of flowering potted plants, supplying the German market. Furthermore, this paper aims to investigate recent developments in the floriculture sector as well as drivers that influence chain actors. Investigating changes and driving forces in the value chain will help the sector to anticipate future developments, and thereby support stakeholders in their future decisions.

\section{Literature review}

A literature review was conducted on horticultural value chains and the driving forces influencing such chains. The first section describes the state of the art regarding horticultural value chains and compares the value chains of food products to cut flowers and potted plant value chains. The second section defines driving forces and emphasizes the importance of adaptation of chains to such forces. The second section also provides an overview of the different driving

TABLE 1. Chain drivers, based on the literature.

\begin{tabular}{|c|c|c|}
\hline Driver & Description & Examples \\
\hline Economic framework & $\begin{array}{l}\text { Changes in life style, tastes, and social condition of the } \\
\text { consumer population can influence consumer demand } \\
\text { and preferences (Porter, 1998; Hobbs and Young, 2000; } \\
\text { Bokelmann and Adamseged, 2016). Demographic devel- } \\
\text { opment, for example, can change the size of the con- } \\
\text { sumer population leading to alternation in demand for a } \\
\text { product (Porter, 1998). Furthermore, changes in industry } \\
\text { structure or changes in adjacent industries can have con- } \\
\text { sequences for chain evolution (Porter, 1998). }\end{array}$ & $\begin{array}{l}\text { Retail structure influenced by internationalization } \\
\text { - Increased price competition } \\
\text { - Higher quality requirements (Bokelmann and } \\
\text { Adamseged, 2016) } \\
\text { General economic conditions can also influence specific } \\
\text { industries } \\
\text { - Financial crises in } 2008 \text { influenced the ornamental } \\
\text { plant industry and forced out a number of firms } \\
\text { (Hall, 2011) }\end{array}$ \\
\hline Natural environment & $\begin{array}{l}\text { The horticultural sector is dependent on the natural en- } \\
\text { vironment as supply quantity and quality is influenced } \\
\text { by biological variations connected to weather conditions } \\
\text { and pest infestations (Bloemhof et al., 2015; Bokelmann } \\
\text { and Adamseged, 2016). Furthermore, increasing climatic } \\
\text { variability attributed to climate change is another factor } \\
\text { that adds to supply risk (Bokelmann, 2009; Bokelmann } \\
\text { and Adamseged, 2016). }\end{array}$ & $\begin{array}{l}\text { - Weather dependent yields of horticultural crops, } \\
\text { cultivated in the field are directly exposed to changing } \\
\text { weather conditions }\end{array}$ \\
\hline Politics and regulation & $\begin{array}{l}\text { The socio-political environment also affects the value } \\
\text { chain (Bourlakis and Weightman, 2004). Government } \\
\text { can directly affect chain actors through national and inter- } \\
\text { national regulations that influence market entry, competi- } \\
\text { tive practices, or profitability (Porter, 1998). Consumer } \\
\text { concerns about safety, liability and traceability of the } \\
\text { product (Hobbs and Young, 2000; Bourlakis and Weight- } \\
\text { man, 2004) can initiate further forms of regulation such } \\
\text { as voluntary standards on quality, safety or environmen- } \\
\text { tal quality of a product (Porter, 1998). }\end{array}$ & $\begin{array}{l}\text { Changes in legal requirements } \\
\text { - Product liability: requirements for the traceability of } \\
\text { the products and the need for certification (Bokelman } \\
\text { and Adamseged, 2016) }\end{array}$ \\
\hline $\begin{array}{l}\text { Innovation and } \\
\text { technological progress }\end{array}$ & $\begin{array}{l}\text { Innovation can contribute to industry evolution (Porter, } \\
\text { 1998). Porter (1998) describes three types of innovation: } \\
\text { product, process and marketing innovations. Process } \\
\text { innovations are developments in the manufacturing pro- } \\
\text { cess or methods (Porter, 1998). In the agri-business sec- } \\
\text { tor, such developments leads to improved efficiency and } \\
\text { increase productivity (Bourlakis and Weightman, 2004) } \\
\text { or alternatively, reduce costs through large scale produc- } \\
\text { tion or quality control (Hobbs and Young, 2000). Product } \\
\text { innovations affect product characteristics such as perish- } \\
\text { ability or differentiation (Porter, 1998; Hobbs and Young, } \\
\text { 2000). Change in product characteristic can either wid- } \\
\text { en the market or alter buyer experience and influence } \\
\text { purchasing behavior (Porter, 1998). Marketing innova- } \\
\text { tions can influence the demand through new marketing } \\
\text { themes or channels. Such innovations are designed to } \\
\text { reach new consumers or reduce price sensitivity through } \\
\text { product differentiation (Porter, 1998). }\end{array}$ & $\begin{array}{l}\text { Process innovation: micro-propagation } \\
\text { - Fast and space saving propagation of healthy and } \\
\text { uniform plants } \\
\text { - Method became a commercially accepted practice for } \\
\text { stock plant production (Menrad and Gabriel, 2009) } \\
\text { Product innovations: genetic modification (GM) } \\
\text { - Development of new cultivars, such as color-modified } \\
\text { varieties } \\
\text { - Opportunity for variety improvement for sterile } \\
\text { varieties } \\
\text { - Shorten the development process (Chandler \& } \\
\text { Tanaka, 2018) } \\
\text { Marketing innovation } \\
\text { - Fairtrade cut-flowers as a differentiation strategy } \\
\text { (Riisgaard, 2009) }\end{array}$ \\
\hline
\end{tabular}


forces described in the literature, and explains the choice of the drivers relevant for the current study.

\section{Chain characteristics and the floriculture sector}

Agri-food chains are generally characterized by seasonality in production and global sourcing, variability in quantities and yields due to unpredictable weather conditions and pests, quality decay with time, temperature conditioned transportation and storage and the need for traceability due to quality and product responsibility (Bloemhof et al., 2015). The floriculture sector is also characterized by high uncertainty in supply quality and quantity. Differences to fresh food supply chains can be found in the large diversity of products (plant varieties), market share of sale channels, such as specialized retail for floriculture and supermarket chains for fruits and vegetables, as well as the large number of small and medium-size enterprises (De Keizer et al., 2015). Such differences indicate more diverse marketing channels and higher product differentiation compared to agri-food chains. Furthermore, the value chain of floricultural products is going through transformations in the past 25 years, as more production shifted to countries with more favorable weather conditions and lower production costs (Ferrante et al., 2015)

Although common characteristics exist within the floriculture sector, differences can be found between the supply channels of cut flowers and potted plants. The main trade mechanism for potted plants is direct trade, rather than auctions in the case of cut flowers. In addition, potted plants are supplied through a network of European sourcing as opposed to global sourcing of cut flowers. Furthermore, according to De Keizer et al. (2015), the supply of potted plants is demand driven because production is planned based on customer orders, as opposed to supply driven in the case of cut flowers where production is based on forecasts. Suppliers in demand driven value chains are highly dependent on the customers. Whereas cut flowers are harvested products, comparable to fruits and vegetables, flowering potted plants are viable plants and therefore require different handling techniques. To maintain the quality, post-production conditions have to consider a more complex relationship between flowers and leaves than in cut flowers. Post-production problems include bud and flower abscission (Ferrante et al., 2015).

\section{Driving forces within the value chain}

The transformation processes in the ornamental flower sector can be attributed to different driving forces. According to Porter's model for industry analysis, five forces determine the competition for profit: customers, suppliers, potential entrants, substitute products and rivalry (Porter, 1980, 2008). To adapt to changes in the environment of an industry, firms have to continuously improve, innovate and upgrade over time to maintain their competitive advantage (Porter, 1991). As firms are part of a system, successful upgrading has to involve other actors in the value chain (Porter, 1991).

Bourlakis and Weightman (2004) addressed the driving forces for change in agri-food chains. Though the term "drivers" is not used consistently, recent studies address challenges affecting the chain and strategy adaptation as chain drivers. Bloemhof et al. (2015, p. 103) defined a driver as "a factor that initiates and motivates firms to adopt a strategy".

Hobbs and Young (2000) emphasized that regulatory, technological and socio-economic drivers can affect product characteristics, which in turn change the transaction environment. Such a change in transaction environment can influence the coordination efforts between actors in agri-food supply chains. Bourlakis and Weightman (2004) state that the six key factors that influence agri-food supply chain management are quality, technology, logistics, information technology, the regulatory framework and consumers. Building on these two studies (Hobbs and Young, 2000; Bourlakis and Weightman, 2004), Bokelmann (2009) presented six driving forces that influence actors in German horticultural value chains. The driving forces according to Bokelmann (2009) are the economic framework, political and legal framework, natural environment, social and cultural development, demographic development and technological progress. Hobbs and Young (2000), Bourlakis and Weightman (2004) and Bokelmann (2009) all included technological, socio-economic and regulatory forces as drivers of agri-food chains. Bokelmann (2009) also included the natural environment that can directly influence agricultural produce. Porter (1991) further emphasized the need of firms to innovate. Therefore, the current study focuses on four groups of forces: (i) the economic framework, referring to socio-economic forces, such as market forces, demographic developments and consumer preferences; (ii) the natural environment, such as weather conditions; (iii) politics and regulation, including voluntary regulations such as private standards; and (iv) innovation and technological progress (Table 1).

\section{Materials and methods}

Qualitative research approaches are especially suitable to generate knowledge when the subject of interest is relatively unexplored (Bitsch, 2005; Corbin and Strauss, 2008). As little is known about the value chain of flowering potted plants, a qualitative research approach was chosen. Previous studies have used a qualitative case study approach to explore fresh vegetable value chains (Riedel et al., 2009) and investigate the supply of young plants in the floriculture sector (Verdouw et al., 2010).

Qualitative interviews are a method to explore and record practices. Investigating key actors and material flow requires multiple perspectives of the involved actors (Fusch and Ness, 2015), therefore in-depth interviews were chosen as a data collection method.

Twenty in-depth interviews were conducted in two rounds in the winters of 2016 and 2017. After the first round of seven interviews, the interview guide was adjusted according to the input from the first round. Interviewees included six propagation nurseries, four seed producers, among them one nursery owner that also cultivated potted plants, another two potted plant growers, three distributers, an agricultural certifier, a business consultant and a horticultural marketing and retail expert (Table 2). Propagation nurseries 1 and 5 and distributer 3 were interviewed twice (in 2016 and 2017). Interviews 2, 14, 15 and 16 were conducted with two interview-partners. Moreover, interview 14 took place with actors from different stages in the chain, the $\mathrm{CEO}$ of a grower organization and one of the growers in the organization. Interviewees from different businesses in the value chain were identified through an exhibitor list for an international horticultural trade fair in Essen, Germany (IPM). Subsequent snowball sampling followed, as some interviewees suggested several potential interviewees with different but relevant businesses.

All but two interviews were carried out in person, at the IPM. Two interviews took place in different locations, at a nursery and at a university building. On average, interviews lasted about 45 minutes. The semi-structured interview guide covered different stages from breeding, propagation, 
TABLE 2. List of interviews: type of chain actor, business actions and interviewee role in the business.

\begin{tabular}{|c|c|c|c|}
\hline Type of actor & Business actions & Interview No. & Interviewee role \\
\hline \multirow[t]{3}{*}{ Propagation nursery 1} & Breeding, vegetative and rooted cuttings & 1 & Marketing director \\
\hline & & 2 & Marketing director \\
\hline & & 2 & Supply chain manager \\
\hline Propagation nursery 2 & Breeding, vegetative and young plants ${ }^{1}$ & 3 & Marketing manager \\
\hline Propagation nursery 3 & Breeding, vegetative and rooted cuttings & 4 & Marketing manager and owner \\
\hline Propagation nursery 4 & Breeding, vegetative and young plants ${ }^{1}$ & 5 & Marketing and product manager \\
\hline Propagation nursery 5 & Breeding, mostly vegetative young plants ${ }^{1}$ & 6,7 & $\begin{array}{l}\text { Sales manager Germany } \\
\text { (authorized representative) }\end{array}$ \\
\hline Propagation nursery 6 & Breeding, vegetative, generative, young plants ${ }^{1}$ & 8 & Marketing and product management (EU) \\
\hline Seed producer 1 & Breeding generative and seed production & 9 & Sales manager EU \\
\hline Seed producer 2 & Organic seeds & 10 & Owner, CEO \\
\hline Seed producer 3 & Breeding, seeds and cuttings & 11 & Growing adviser \\
\hline $\begin{array}{l}\text { Seed producer } 4 \\
\text { and grower } 1\end{array}$ & Breeding generative, seeds, seedlings and potted plants & 12 & Owner \\
\hline Grower 2 & Rooted cuttings and potted plants & 13 & Owner, CEO \\
\hline Grower 3 & Breeding generative, seedlings and potted plants & 14 & CEO \\
\hline Wholesaler 1 & Growers' cooperative, distribution & 14 & CEO \\
\hline \multirow[t]{2}{*}{ Wholesaler 2} & Growers' organization, distribution and export & 15 & Sales manager \\
\hline & & 15 & CEO \\
\hline \multirow[t]{3}{*}{ Wholesaler 3} & Growers' cooperative, distribution and export & 16 & CEO \\
\hline & & 16 & Public relations and marketing \\
\hline & & 17 & $\begin{array}{l}\text { Quality management and sustainability } \\
\text { (head of department) }\end{array}$ \\
\hline Certifier & Certification & 18 & Commercial manager \\
\hline Business consultancy & Ecological footprint & 19 & Sales Germany \\
\hline Retail expert & Academic research & 20 & Scientist horticulture and market research \\
\hline
\end{tabular}

${ }^{1}$ Young plants refers to both seedlings and rooted cuttings.

young plants, and logistics to end product, and interviewees were asked to describe the different activities and processes within the value chain. In the second round of interviews, questions about economic challenges were included. Topics were presented according to the conversational flow of the interview and adjusted to each value chain (vegetative or generative) and the value chain stage of the interviewees. All interviews were audio-recorded and transcribed verbatim using the f4 transcription software. The transcription was a simple transcript, focusing on the content and was conducted in the original language of the interview, either German or English.

All resulting documents were systematically analyzed using the qualitative data analysis software Atlas.ti. The analysis followed a hybrid approach, partly concept-driven (deductive) and partly data-driven (inductive). According to Schreier (2012) qualitative data analysis is often combined, data-driven to be able to describe the material in depth and concept-driven because the research question already determines a framework for the analysis. In the current study, production phases served as the initial coding framework. Repeated reading of interview transcripts allowed capturing details on value chain activities and processes. The inductive approach was further applied to explore value chain drivers.

During the coding process, text fragments were marked and a code system was developed to identify activities and processes in the value chain. In later stages, related codes were associated in code families. The analysis and inter- pretation were an ongoing process, to identify patterns in a constant contrast and comparison process (Boeije, 2002). Patterns were identified by comparing text fragments of each code (or code family). Insights were documented during the analysis process. This documentation was also considered for the interpretation of the results.

\section{Results and discussion}

Results and discussion are divided into two sections. The first section is dedicated to the different stages of the value chain. In each stage, processes and activities identified in the current study are discussed in comparison to published literature. Furthermore, differences between the vegetative and generative pathways of the value chain, such as differences in breeding, production locations, post-harvest processing and perishability of the propagation material are discussed. The second section builds on understanding the characteristics of the value chain and explores the driving forces within the value chain.

\section{Value chain stages}

The supply chain of potted plants has changed in the past 25 years, as growers became more specialized. According to interviewees, propagation nurseries started to deliver young plants, taking over a work stage that was done previously by potted plant growers. Specialization in different production stages had been reported for the floriculture sector (De Keizer et al., 2015), but not specifically for the potted plant value chain. 


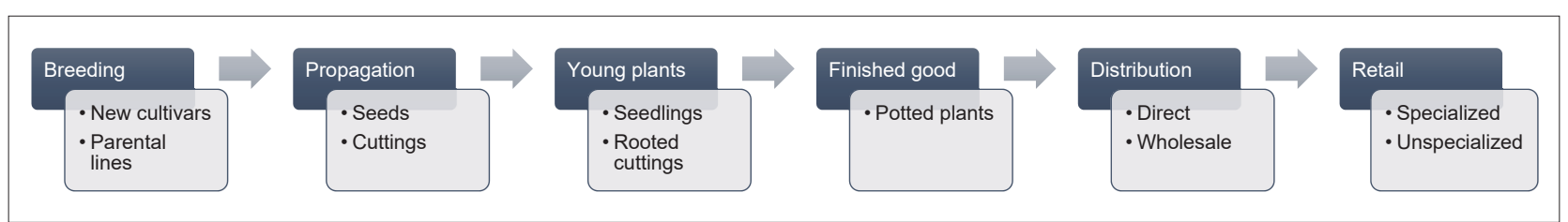

FIGURE 1. Value chain stages of flowering potted plants.

The value chain can be divided into two pathways that are distinct due to the propagation method, either generative (seeds) or vegetative (cuttings). Although in-vitro propagation is used for the propagation of plants such as orchids and Anthurium, the majority of flowering potted plants are still propagated from cuttings or seeds. Chain material flow starts at the breeding and propagation level. The propagation material is supplied to young plant nurseries; young plants are then distributed to potted plant nurseries and the finished product is supplied through wholesalers or directly to retail (Figure 1).

1. Breeding and propagation. Breeders are responsible for all new varieties and distribute propagation material worldwide. Based on the interviews with propagation nurseries, breeding of cultivars with new and attractive traits of shape and color is an important part of the business, as such novelties are the capital of the breeders. Therefore, propagation nurseries invest significant funds in the development of novelties, also including other breeding goals, such as disease resistance, temperature tolerance, longer shelf-life, and early bloom. As the development of new cultivars can take up to ten years, breeders have to anticipate long-term market trends and adjust breeding efforts accordingly. Shibata (2008) claimed that the need to continuously develop and release new cultivars to the market is due to consumers' preferences for new varieties. Some plants such as red and white poinsettias stay popular, but also among such plants, plenty of different varieties of color shades are available with new developed cultivars coming out yearly.

Traditional breeding techniques are used for the development of new varieties, such as cross-hybridization, selection and mutagenesis. Breeding of vegetative and generative cultivars is a similar process. Nevertheless, vegetative cultivars are not limited by the need for seed production, and therefore allow more possibilities for size, colors and patterns of flowers, evident in current varieties of Petunia and Pelargonium. According to Faust et al. (2016), breeding programs for seed production are more time consuming and costly because of the need to provide sufficient numbers of seeds with high germination rates.

After attaining the desired qualities, the new variety is tested before it can be commercially distributed. The major-

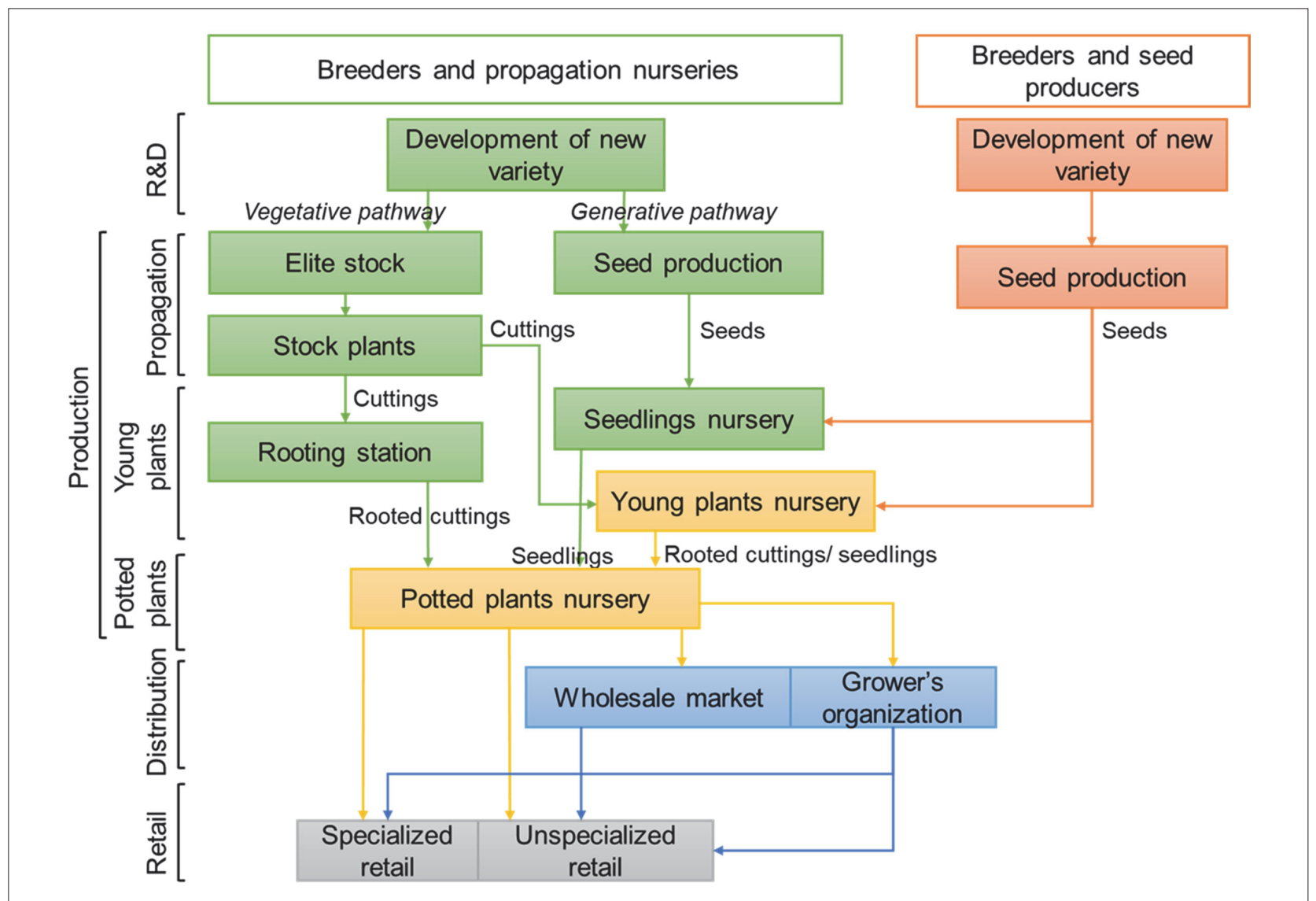

FIGURE 2. General overview of the value chain of flowering potted plants. Green: breeders and propagation nurseries; orange: breeders and seed producers; yellow: young plants and potted plants nurseries (independent from breeders); blue: distribution; gray: retail. 
ity of breeders specialize in either vegetative or generative cultivars. Breeders that develop generatively propagated varieties produce seeds. Breeders that specialize in vegetatively propagated cultivars produce cuttings and young plants (Figure 2).

There are few companies worldwide, which specialize in breeding and seed production of a large assortment of flowering plants. McDonald and Kwong (2005) also found that seed supply is dominated by a few international flower seed companies from the USA, Japan and Europe. There are, however, also small producers specializing in few or single plant species. Production of seeds takes place in various locations around the world, including China, Central and South America, the USA, Africa and Europe. According to interviews with seed producers, the most important criteria for the choice of production location is optimal climate condition. Favorable locations have a mild climate, suitable for the cultivation of many plant species, and enable year-round production. Some crops, however, such as Primula, grow best under colder temperatures and are cultivated primarily in Europe.

Seed production is labor intensive, which is why labor costs are another important criterion for the choice of location. Based on interviews, seed production takes place in greenhouses or in the field by either cross-breeding to create $\mathrm{F}_{1}$-hybrids or by open-pollinated varieties. Controlled conditions are preferred to achieve better quality and prevent pollen contamination. Seed producers explained that harvested seeds are cleaned by shape and size specific machines. Seed enhancement treatments are performed to ease handling by automatic seeders, accelerate the germination and induce uniform growth. In some cases, seeds are also treated against pathogens. Quality of seeds is tested to determine the germination rate.

According to interviewees, seeds are relatively stable and can be stored for long periods, depending on the crop. Due to their stability and low weight, seeds are distributed worldwide mainly by postal services or global logistics companies, and generally do not require temperature-controlled transport (Figure 3A). Seed producing companies distribute seeds either directly to seedling producers or through seed distributers (wholesale).

For vegetatively propagated cultivars, propagation nurseries produce cuttings and rooted cuttings. These companies play a central role in the value chain as they develop new varieties, supply propagation material and produce young plants. Company headquarters are mainly in Germany and the Netherlands, and are internationally active with worldwide distribution.
Elite stock plants are cultivated in Europe under strict hygienic conditions to prevent contamination (Figure 3B). Stock plants are propagated from elite stock plants and are the source for cuttings supplied to the European market. Stock plants are generally cultivated in African countries such as Kenya, Ethiopia, Uganda, and Tanzania. Some breeders also cultivate stock plants in Central America. Cuttings are harvested from stock plants cultivated in greenhouses under hygienic conditions. Harvested cuttings go through quality control, are packaged in cardboard boxes and air-shipped on the same day. From the airport, cuttings are transported in climate-controlled vehicles. To maintain quality, cuttings should reach the grower within three to five days from harvest.

The European supply of cuttings and young plants is orchestrated by propagation nurseries concentrated mostly in the Netherlands and Germany. These findings are supported by Menrad and Gabriel (2009) stating that the Netherlands and Germany are the largest producing countries in Europe for young plant material for potted plants and cut flowers. Menrad and Gabriel (2009) also refer to the well-established infrastructure for knowledge generation and innovation in horticulture in the Netherlands and Germany. Evers et al. (2014) further claimed that the global trade in cuttings was largely controlled by a few propagation nurseries located in the Netherlands, Germany and Switzerland. Interviewees from German, Dutch and Swiss firms confirmed that they supply cuttings to producers worldwide. The local competition and the transfer of knowhow due to the geographic proximity of propagation nurseries enabled those firms to become successful.

2. Young plants. Young plants are produced by propagation nurseries, collaborating contractors and independent growers (Figure 2). According to interviewees from propagation nurseries, young plants for the European market are generally produced within Europe, and distributed in climate-controlled vehicles. Interviewees also claimed that young plant production has become very effective, to achieve the required quality on time. The production of young plants takes place in state-of-the-art greenhouses under controlled temperature and humidity. Whereas seeds are sown by automated seeders, cuttings are generally hand planted. Seedling producers explained that cultivation duration of seedlings is diverse depending on the plant and the size of the product. For example, Viola need about five weeks and Cyclamen twelve weeks. Cultivation of cuttings is generally shorter, requiring between three to six weeks to develop roots.

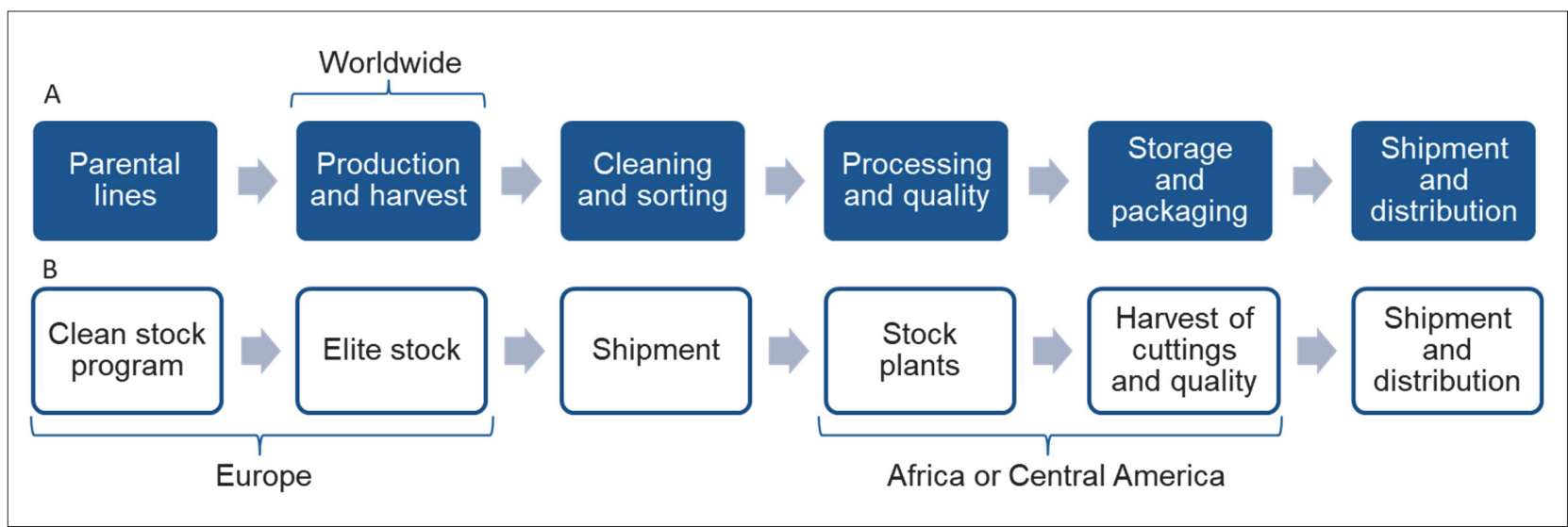

FIGURE 3. Stages in the production of propagation material: seeds (A); cuttings (B). 
3. Flowering potted plants. The cultivation of potted plants is a separate production phase with different growing conditions and treatments. Whereas young plant production is standardized to be able to deliver the required quality ontime, potted plant production depends on the scale of production and the assortment. Young plants are potted and cultivated under suitable conditions of light, temperature, irrigation, fertilizer, and humidity. Additional activities might be required, such as pinching for branching, as well as staking and tying for support.

Distribution channels influence the production requirements. Therefore, potted plant growers can be classified according to their distribution strategy and choice of assortment. The first group typically produce commodity plants and distribute directly to large retail chains or large cooperatives. Such growers have strict production times, because the supply date is predetermined, and the space is needed for the next culture. The second type of growers focuses on a specialty assortment. Such growers supply generally to specialized retailers of flowers and potted plants. The third group grow and directly sell specialties. In accordance with this classification of growers, evidence for distinct marketing channels of orchids was reported for large retail chains and specialized retail (Krause et al., 2015). De Keizer et al. (2015) also referred to a clear distinction between the assortments of commodity and specialty plants.

4. Distribution of the finished product. Potted plants are generally distributed either through grower organizations or directly to retail. According to one interviewee, a large grower organization and retail chains tend to work with growers that have the capacity for large-scale production. Small growers may sell their products directly. Another form of distribution are wholesale markets, where growers and specialized retailers trade flowers and plants (Figure 2). Grower organizations are an important distribution channel for flowering potted plants. The strategies of grower organizations to achieve a higher price include marketing innovations and differentiation. The largest horticultural grower organization in Germany has several distribution channels: (i) customers' orders and delivery through local logistic centers, (ii) cash-and-carry (C\&C) markets for specialized retailers, and (iii) a flower auction hall located in a large horticulture region.

5. Retail. The growing market share of supermarket chains and discounters has led to their increasing power in the value chain. According to interviewees, the number of florists continues to decline due to high rental costs in city centers and the competition with retail chains. Consumer shift from specialized flower shops to retail chains was shown for the German and European markets and explained by the preference for one-stop-shopping (Gabriel and Menrad, 2013; De Keizer et al., 2015).

According to Porter (2008), buyers become powerful when few large buyers purchase relatively large volumes. Such buyers can request reduced prices, demand better quality (increasing costs) and generally increase competition among industry participants. Supermarket chains and discounters can be considered powerful buyers because they buy large quantities and therefore are able to demand reduced prices. For orchids, this strategy was confirmed by Krause et al. (2015). As a result, potted plants sold by retail chains differ in price and quality from those sold by specialized retailers. Moreover, according to interviewees, retail chains also set standards for potted plant suppliers regarding pesticide use and certification. Evidence of the power of retail chains was shown already for other horticulture sectors. Riedel et al. (2009) concluded that fresh vegetable value chains are governed by large retail chains, which set the rules and participation conditions for producers. Value chains of cut flowers, not distributed through auctions, are also governed by large retailers setting criteria regarding quality, price, logistics and production processes (Riisgaard, 2009).

While dividing tasks among specialized agents may increase efficiency of operations, multiple chain actors also require more challenging coordination efforts. Moreover, tight coordination is vital in the value chain of flowering potted plants due to perishability. The need for on-time delivery to retail influences the entire chain and requires coordination between all actors from propagation material to distribution of the finished product. This means that orders have to be made early, and plants (propagation material, young plants) have to be delivered in a timely manner to the next stage of production. Growers have to prepare for the new delivery in terms of space and workforce. The duration of production is planned by the day, and distribution has to be tightly coordinated. For example, because cuttings are very sensitive, a delay of even one day may threaten the success of the entire crop. Furthermore, as this is a living plant, the successful production and distribution is dependent also on external factors such as weather conditions, or pathogen infestation. According to interviewees, delivering good quality on time is extremely important for their reputation as a reliable supplier. In fact, delivering the right quality at the right time was already mentioned, as an added value, more important than speed by De Keizer et al. (2015). The need for closer vertical coordination was anticipated for agri-food (Hobbs and Young, 2000) and horticultural chains (Bokelmann, 2009). According to Hobbs and Young (2000) perishability is indeed increasing coordination efforts among chain actors, because coordination reduces the uncertainty of the buyer regarding the quality and reliability of supply and sellers' uncertainty in locating a buyer in a timely manner to avoid product deterioration.

\section{Driving forces within the value chain}

1. Economic framework. The German market is considered stable with minimal changes in market volume. Nevertheless, there is a growing concern among actors for the future of the floriculture sector. Generational changes are feared to result in a reduction in the consumer base, because young consumers have different preferences. On the contrary, Ludwig-Ohm and Dirksmeyer (2013) expected an increase in consumption, because the consumer groups spending most on ornamental plants (older than 55 and couples without children) are expected to grow.

In the current study, interviewees claimed that young consumers cannot appreciate plant quality, lack the knowledge on different plant species, and spend little time in gardening. Therefore, young consumers prefer to purchase mature products and finished arrangements. Furthermore, interviewees referred to the need to "tell a story" about the plant as a marketing strategy. Product differentiation strategies are developed by breeders or grower organizations and require growers to collaborate. Indeed, according to De Keizer et al. (2013), future competitiveness in potted plant chains will require more collaboration between actors to achieve differentiated marketing channels.

Based on interviewees, the German market is limited, therefore, grower organizations put efforts into expanding to new markets such as Eastern Europe. De Keizer et al. (2015) 
also referred to Eastern Europe becoming a significant market for luxury products, such as cut flowers, due to improving economic conditions.

One of the most dominant factors affecting actors in the value chain is the low market price. Actors (breeders, growers and grower organizations) claimed that the downward "price pressure" coming from retail chains caused great difficulties for their businesses, and was one of the driving factors for relocating the production sites of propagation material to countries with low labor costs. Faust et al. (2016) also described a trend of stock plant production facilities to move to countries with low wages. Seed producers also reported to have relocated the production to locations with lower labor costs. Some actors claimed that the low prices can be explained by consumers' perception of plants as a cheap product. Ludwig-Ohm and Dirksmeyer (2013) also recognized that the end consumer does not appreciate the sophisticated plant production technology and knowhow that is required in horticulture.

Lack of prestige is often associated with difficulties in hiring employees. Ludwig-Ohm and Dirksmeyer (2013) linked the traditional image of the horticulture sector with the lack of interest of young people in pursuing horticultural careers. According to some actors, businesses struggle due to the shortage in personnel and difficulties in keeping employees motivated and loyal. A representative of an international seed company also reported that there are fewer students specializing in traditional plant breeding. Bokelmann (2009) anticipated a shortage of trained employees for the horticulture sector due to a low number of apprentices, which was confirmed by Ludwig-Ohm and Dirksmeyer (2013).

2. Natural environment. Unpredictable weather conditions are another challenge for potted plant growers. Although potted plants are mostly cultivated in protected environments, weather conditions still influence greenhouse production. In warm winters, bedding plants will mature too early. The demand for bedding plants is also weather-dependent. Consumers are more likely to purchase outdoor plants when the weather is warm and sunny. Moreover, they require early varieties which are temperature-resistant and bloom early. Verdouw et al. (2010) also reported that weather-dependent sales contributed to demand uncertainties in the floriculture sector. Brumfield (2010) even considered weather as more challenging than economic recessions.

Healthy vegetative propagation material is important to prevent pathogen transmission between the different production stages. To maintain healthy stock plants, vegetative propagators must follow a hygiene protocol (clean stock programs). Following this protocol, elite stock plants are cultivated in-vitro, and tested and treated against viruses and other pathogens. Elite stocks, which are the source for propagation material for stock plans, are also cultivated in more than one location for backup. Stock plants in Africa and Central America are also cultivated under strict hygienic conditions and in multiple locations. To maintain hygienic conditions, special ventilation filters are installed and irrigation water goes through advanced purification systems. Faust et al. (2016) confirmed the need for sanitation protocols to prevent pathogen infections that can jeopardize the entire harvest of cuttings.

3. Politics and regulations. European legislation prohibits import of plants of the Solanaceae family from non-European countries other than Mediterranean countries to prevent pathogen transmission to food crops such as tomatoes and potatoes (European Commission Directive 2000/29/EC). As a result, stock plants of the Solanaceae family (e.g., Petunia, Calibrachoa) are cultivated mostly in Southern Europe and Mediterranean countries. Some propagation nurseries have their own production sites in Europe (generally in Portugal or Tenerife). Others collaborate with growers in Israel to produce Solanaceae cuttings. In this case, "private stock" varieties, developed by the partner company, are reserved to the collaborating propagation nursery.

Minimum wage was introduced in Germany in January 2015. One grower reported that the minimum wage created difficulties, because costs cannot be transferred to the price of the product. As a result, the company had to reduce the workforce. Minimum wage does not seem to be an obstacle for wholesalers, exporting plants. An interviewee working at wholesale claimed to pay more to be able to hire workers at all. The difference in the attitude towards minimum wage could be explained by the different firms' locations that might influence wages paid. Furthermore, production workers tend to earn lower wages, although, according to experts, most horticultural wages were already meeting the minimum wage before the implementation of the law (Bitsch et al., 2017).

Propagation nurseries benefit from lower production costs and optimal weather conditions for cutting production in Africa. Some interviewees claimed that they were "pushed" to work in such locations, due to the price pressure. Moreover, according to interviewees, working in Africa is also associated with personal risk as European gardeners have been exposed to violent attacks. Faust et al. (2016) claimed that one of the most important conditions for stock plant production location is the political stability of the host country. Yet, important production countries, such as Kenya and Ethiopia, suffer from political instabilities and personal safety issues. According to newspaper reports, some attacks on foreign-owned horticultural farms took place in Ethiopia during September and October of 2016. Protestors accused the Ethiopian government of seizing land for little compensation (Secorun, 2016).

Non-governmental organizations (NGOs) also play an important role in influencing chain actors to adopt private standards. Chain actors including propagation nurseries, growers and retailers are taking measures to prevent media scandals. They claimed that NGOs cause negative media attention. Propagation nurseries adopted certification programs to increase transparency and also made efforts to improve the social conditions at the production sites in developing countries. Such programs generally include medical care, day care for working mothers, and training and education programs for employees. Furthermore, these production sites are also socially certified (e.g., MPS Socially Qualified or GLOBALG.A.P. GRASP).

Certifications have become a requirement for the entire value chain. Retail chains buy only certified products in an effort to reduce risk. Indeed, all actors interviewed, including breeders, growers and grower organizations were certified by either MPS or GLOBALG.A.P. Small potted plant nurseries are often not certified, due to the associated costs and the administrative burden. As a result, non-certified growers are excluded from distribution to retail chains.

Some retail chains introduced a new requirement for neonicotinoid-free plants. The neonicotinoids might be linked to the reduction in pollinators and are, therefore, controversial (Kerr, 2017). According to interviewees, to avoid neonicotinoids some growers reported to have used generally more pesticides (some reported twice as much), and 
substances more harmful for both insects and humans than neonicotinoids. Growers also claimed that each retail chain was listing different substances that are prohibited, which would make it even more difficult to comply. Furthermore, a new certification was introduced, MPS-ProductProof, to certify neonicotinoid-free plants.

Reactions of horticultural chain actors to NGO pressure was also shown by Riedel et al. (2009), for fresh vegetables when retailers required new standards for pesticide use. Getter et al. (2016) referred to retail specific requirements on the use of neonicotinoids in ornamental plant production in the USA. Evers et al. (2014) also claimed that international NGOs were putting pressure on European flower buyers (largely supermarkets) regarding working conditions in the supply chains. Whereas the former studies discussed retailers' reactions to pressure, in the current study, also other actors, such as propagation nurseries, reported taking measures to avoid media attention.

The requirement for certification by large retail chains in Germany was shown already for orchids (Krause et al., 2015), while claiming that certification was not an important criterion for the end consumer. Accordingly, the requirement for certification would be a measure to minimize risk rather than a strategy for product differentiation. Furthermore, Riisgaard (2009) claimed that certification was a way to redistribute the costs to suppliers.

\section{Innovation and technological progress.}

Product innovations. So far, genetically modifying (GM) technologies were considered too expensive for the development of new cultivars for the floriculture industry (Chandler and Tanaka, 2018). Moreover, the usage of GM technologies is controversial and the cultivation of GM crops is substantially banned in Europe (Tagliabue, 2017). While breeders claimed to use only traditional breeding techniques, one of the breeders interviewed did not rule out using GM techniques, if costs are reduced. Another company stated to investigate genes that are responsible for coloring in flowers. In the past years, new and less expensive gene editing technologies, such as CRISPR/Cas have emerged. This technology was already implemented for mutagenesis in Chrysanthemum morifolium and Petunia (Zhang et al., 2016; Kishi-Kaboshi et al., 2017). Gene editing technology was considered by many plant breeders and scientists equivalent to mutagenesis technologies, which are exempt from the European regulations on genetically modified organisms (GMO) (Callaway, 2018). However, a recent decision by the European court (July 2018) subjects gene editing technology to the obligations laid down by the GMO Directive (Court of Justice EU, 2018). Though genetically engineered varieties are currently not accepted in European countries, the lack of an internationally coordinated approach to regulation (Chandler and Tanaka, 2018) and future change in regulation leave some potential for GM varieties especially in other markets, such as the USA and Japan.

Peat is the main component of growing media in horticulture due to a unique combination of properties that provide highly favorable conditions for plant growth. Yet, harvesting of peat is associated with habitat destruction and contribution to climate change, as peatlands are crucial sinks for carbon in the terrestrial ecosystem (Méndez et al., 2015). According to interviewees, different peat substitutes are available in the market. Growers reported different levels of success with substitutes. Nevertheless, the majority of growers are still using peat-based substrates as the main growing media. Barrett et al. (2016) confirmed that although many of the renewable substitutes show promise at an experimental level, few have been adopted commercially at a significant scale. According to Barrett et al. (2016), for growing media to be commercially acceptable they have to achieve acceptable results for a variety of plant species and under different irrigation, fertilizer and pest control regimes. Furthermore, the comparative environmental costs and benefits of different growing media need to be determined to avoid the adoption of substrates that are even more environmentally harmful than peat (Barrett et al., 2016).

Process innovations. Light emitting diode (LED) technology has the potential to replace high pressure sodium lamps (HPS), commonly used for horticultural purposes. LEDs are considered more energy-efficient and the light spectrum can be adjusted according to need (Bergstrand and Schussler, 2013). LED technology was reported to be implemented in logistic centers, marketplaces and C\&C markets as a way to reduce energy consumption. Large growers cultivating crops with assimilation light requirements might already use LEDs. The limitations for the adoption of LEDs is the high price and the complexity of realizing the full potential of the technology. For example, LEDs can be used for the production of compact plants, a desired quality in the morphology of ornamental plants (Schwend et al., 2015). However, results were shown on a model plant in a controlled experiment and not in a commercial environment. Therefore, successful implementation requires knowhow and return on investment remains uncertain.

Automation plays an important role especially in the production of young plants by reducing labor costs. Automatic seeders are used for seedling production. According to Faust et al. (2016) seed propagation is often the preferred means of propagation because of the ease of automation. Though robots for planting cuttings are available, the majority of cuttings are still manually planted. According to Adegbola et al. (2019), robotic transplanting of cuttings is cost-effective in case of high local wages and low manual labor efficiency.

Insect pollination, where bees and bumblebees replace the process of hand pollination, is a method implemented by seed companies to save on labor costs. One seed producer has implemented insect pollination successfully at a European production site. Nevertheless, another producer claimed that insect pollination is not feasible because insect pollination requires a separate hall for each variety. This technology might be applicable for seed production in industrialized countries, where labor costs are high; however, it requires restructuring the production.

5. Marketing innovations. Sustainability is viewed as a market opportunity and there is a growing effort for product differentiation. The market for Fairtrade cut flowers is already established in Germany with 28\% market share (Fairtrade, 2017). Fairtrade plants such as poinsettia and Pelargonium are new in the market. The number of Fairtrade poinsettia sold was 890,000 plants in 2017, with an increase of $6 \%$ compared to 2016 (Fairtrade, 2017). Fairtrade plants are controversial as some actors claimed that most consumers are not aware that the propagation material is cultivated in developing countries, and therefore do not understand the relevance. In addition, some specialized retailers were reluctant to buy Fairtrade plants, due to the premium price. Consumer acceptance of Fairtrade potted plants is still to be determined.

Another trend observed is the reduction in use of pesticides and successful application of biological pest control. Two examples of products associated are bee-friendly plants 
and organic plants. Bee-friendly labeled products are plants that were treated with reduced amounts of pesticides harmful to insects and have attractive flowers for pollinators. Bee-friendly plants are an innovation, related to consumer awareness of the population decline of pollinator insects linked with pesticide use. Using the term "bee-friendly" received greater willingness-to-buy compared to plants labeled as "neonicotinoid-free" (Getter et al., 2016).

Organic products are still rare in the floriculture industry. However, organic production was reported by several seed producers who are also partly certified organic. Research on consumer preferences for organic ornamental plants was conducted mostly for the USA market. Yue et al. (2011) found that consumers were not enthusiastic about organically grown ornamental plants. On the contrary, Rihn et al. (2016) showed increasing probability of purchases for certified organic and organic production attributes for indoor foliage plants.

\section{Conclusions}

The value chain is geographically fragmented in several production steps contributing to production efficiency and better quality. Geographic fragmentation is typical also for other horticultural chains, but for potted plants only the propagation material is cultivated in southern countries, such as Africa and Central America. Yet, chain fragmentation complicates coordination efforts, which are essential due to perishability and the requirement for on-time delivery. Moreover, perishability of the product, especially of cuttings requires high coordination between chain actors in order to reduce buyer and suppler uncertainty. Marketing and differentiation further require close coordination between actors because such efforts are initiated already at the breeding level and continue all the way to retail.

Vegetative propagation has become popular due to attractive cultivars and shorter cultivation periods of young plants. Nevertheless, cuttings have a short shelf-life, and generally require manual planting and costly sanitation protocols. Different from cuttings, seeds have a long shelf-life, do not require climate-controlled transportation and are automatically sown. Still, seeds require after-harvest processing and quality tests. Moreover, the vegetative pathway relies on cutting production in Africa, which is risky, because of political instability. To secure the supply of cuttings, breeders must cultivate in multiple production sites. Profitable production of seeds also requires low-wage labor. But since seeds are a stable product, they can be easily stored and transported around the world.

Breeders control the supply of propagation material and offer a large variety of patented cultivars. However, substitutes are easily available by competitors, which reduces breeders' bargaining power. Local competition due to geographic concentration results in decreasing margins reported by propagation nurseries, but it also triggers innovation and upgrading, which contribute to successful global trade. Sophisticated demand from retail chains also stimulates competitive success by anticipating buyers' needs elsewhere. To avoid losses due to unpredictable weather conditions, growers will have to find solutions to slow the maturation of plants in warm winters. While a supply-side solution might be available, it is more challenging to control weather-dependent demand uncertainties. Consumers appreciate diversity and new varieties, and breeders try to differentiate themselves by offering unique cultivars. While some niche markets do exist and will re-develop for heritage varieties, they also need to be developed through breeding and marketing. Development of new cultivars is a long and costly process. Gene editing technologies can potentially reduce the costs of development, but are not currently allowed for the European market.

Potted plant growers are the group of actors with the least bargaining power and they face difficulties to stay competitive. They can be divided according to their competitive strategy. Large scale production enables growers to lower the costs per plant. Such growers generally produce commodity plants, and distribute directly to retail chains or alternatively to a large cooperative. Another strategy is producing specialty plants and distribution through a grower organization or other distribution channels such as wholesale markets. The focus here is on product differentiation through marketing innovations and diversity of assortment. The third strategy is also characterized by a specialty assortment, selling directly at the nursery. Such growers generally sell products regionally, avoid membership costs in grower organizations and certification fees.

Similar to other agricultural value chains, retail chains for flowering potted plants are powerful buyers. The requirement for certification is an entry barrier for growers wishing to supply this marketing channel, because it imposes more costs and administrative burdens, and uncertified growers are excluded from distribution through retail chains. Certification requirements might also contribute to standardization in the sector, as most actors follow similar certification standards. Another indication of retailers' powerful position is the risk distribution in the chain. Unpredictable weather conditions as well as pathogen infestation pose a high risk for growers because of financial loss, and they also risk their reputation as reliable suppliers. Weather-dependent demand also poses a risk to retailers. Other forces such as changes in consumer preferences require the reaction of all chain actors, from breeder to retailers, in order for the companies to stay competitive.

Contrary to other sectors, in floriculture, NGOs influence other chain actors, in addition to retailers, directly. Retailers also put substantial pressure on other chain actors. For example, when retailers prohibited the use of neonicotinoids, growers used more harmful pesticides. Sudden requirements without an adaptation period can have unfavorable results. Therefore, retail chains should consider gradual transition periods to allow growers to develop suitable solutions.

Public awareness and NGO pressures motivate growers to reduce pesticide use and search for alternative strategies for pest control such as beneficial insects. These efforts are visible in marketing innovations such as bee-friendly plants. Product innovations, like peat-free potted plants, have the potential for product differentiation to attract environmentally conscious consumers. However, successful implementation requires experimenting to find suitable substrates. Process innovations such as LED technology, which offers several potential benefits, require high investments and expertise. Other innovations such as robots for planting cuttings can reduce labor costs, but are also associated with large investments.

Concerns regarding the future of the sector drive actors to strive for costs reduction, and to increase the consumer base by attracting young consumers and expanding into other markets. This strategy works under prosperity market conditions. However, the ornamental industry is more susceptible to lower demand during recessions than other horticultural industries, as was observed during the financial crisis in 2008. The popularity of organic, bee-friendly or 
peat-free products is expected to grow due to the increasing public awareness of sustainability issues in the value chain. Nevertheless, consumer research is needed to support actors in their differentiation efforts. Future research could also address the sustainability challenges of such complex and fragmented value chains. Better understanding of the sustainability challenges could help actors to reduce their environmental and social impacts and improve their competitive advantage.

\section{Acknowledgments}

The authors wish to thank the interviewees for sharing valuable information about the value chain. Special thanks also go to Dr. T. Schwend for his contribution to data collection, as well as to Dr. M. Rombach and Dr. A. Gabriel for their advice and support during the writing process. This research was funded by the Bavarian Ministry of Education and Culture, Science and Arts.

\section{References}

Adegbola, Y.U., Fisher, P.R., and Hodges, A.W. (2019). Economic evaluation of transplant robots for plant cuttings. Sci. Hortic. 246, 237-243. https://doi.org/10.1016/j.scienta.2018.10.070.

AMI (2019). Markt Studie. Warenstromanalyse 2018: Blumen, Zierpflanzen \& Gehölze. https://www.bmel.de/ SharedDocs/Downloads/Landwirtschaft/Pflanze/Gartenbau/ warenstromanalyse-2018.pdf?_blob=publicationFile.

AMI (2020). Zierpflanzenmarkt 2019. Märkte: Blumen und Zierpflanzen. https://www.ami-informiert.de/ami-maerkteblumen-zierpflanzen/meldungen.

Barrett, G.E., Alexander, P.D., Robinson, J.S., and Bragg, N.C. (2016). Achieving environmentally sustainable growing media for soilless plant cultivation systems - A review. Sci. Hortic. 212, 220-234. https://doi.org/10.1016/j.scienta.2016.09.030.

Bergstrand, K.J., and Schussler, H.K. (2013). Growth, development and photosynthesis of some horticultural plants as affected by different supplementary lighting technologies. Eur. J. Hortic. Sci. 78 , 119-125.

Bitsch, V. (2005). Qualitative research: A grounded theory example and evaluation criteria. J. Agribus. 23, 75-91.

Bitsch, V., Mair, S., Borucinska, M.M., and Schettler, C.A. (2017). Introduction of a nationwide minimum wage: challenges to agribusinesses in Germany. Economia Agro-Alimentare 19, 13-34. https://doi.org/10.3280/ECAG2017-001002.

Bloemhof, J.M., Van der Vorst, J.G.A.J., Bastl, M., and Allaoui, H. (2015). Sustainability assessment of food chain logistics. Int. J. Logist. Res. Appl. 18, 101-117. https://doi.org/10.1080/13675567.2015.1015 508.

Boeije, H. (2002). A purposeful approach to the constant comparative method in the analysis of qualitative interviews. Qual. Quant. 36, 391-409. https://doi.org/10.1023/A:1020909529486.

Bokelmann, W. (2009). Wertschöpfungsketten im Gartenbau. In Status quo und Perspektiven des deutschen Produktionsgartenbaus, W. Dirksmeyer, ed. (Braunschweig, Germany: Thünen-Institut), p. $115-129$

Bokelmann, W., and Adamseged, M.E. (2016). Contributing to a better understanding of the value chain framework in developing countries. $5^{\text {th }}$ International Conference of the African Association of Agricultural Economists, Addis Ababa, Ethiopia.

Bourlakis, M.A., and Weightman, P.W.H. (2004). Food supply chain management (Oxford: Blackwell). https://doi. org/10.1002/9780470995556.
Brumfield, R.G. (2010). Strategies producers in the Northeastern United States are using to reduce costs and increase profits in tough economic times. HortTechnology 20, 836-843. https://doi. org/10.21273/HORTTECH.20.5.836.

Callaway, E. (2018). CRISPR plants now subject to tough GM laws in European Union. Nature 560, 16. https://doi.org/10.1038/d41586018-05814-6.

Chandler, S.F., and Tanaka, Y. (2018). Transgenic research in floricultural crops. In Genetic Engineering of Horticultural Crops, G.R. Rout, and K.V. Peter, eds. (Amsterdam: Academic Press), p. 121136. https://doi.org/10.1016/B978-0-12-810439-2.00006-4.

Corbin, J., and Strauss, A. (2008). Basics of Qualitative Research ( $3^{\text {rd }}$ ed.): Techniques and Procedures for Developing Grounded Theory (Thousand Oaks: Sage Publications, Inc.). https://doi. org/10.4135/9781452230153.

Court of Justice EU (2018). Organisms obtained by mutagenesis are GMOs and are, in principle, subject to the obligations laid down by the GMO Directive. Press release no 111/18. Judgment in Case C-528/16 (Luxembourg).

De Keizer, M., Van der Vorst, J.G.A.J., Bloemhof, J.M., and Haijema, R. (2015). Floricultural supply chain network design and control. Industry needs and modelling challenges. J. Chain Network Sci. 15, 61-81. https://doi.org/10.3920/JCNS2014.0001.

Evers, B., Amoding, F., and Krishnan, A. (2014). Social and economic upgrading in floriculture global value chains. Flowers and cuttings GVCs in Uganda. Capturing the gains. Working Paper 42, (Univ. of Manchester). https://doi.org/10.2139/ssrn.2456600.

Fairtrade (2017). Transfair E.V. Jahres- und Wirkungsbericht 2017. Marktübersicht. https://www.fairtrade-deutschland.de/service/ mediathek.html.

Faust, J.E., Dole, J.M., and Lopez, R.G. (2016). The floriculture vegetative cutting industry. In Horticultural Reviews, Vol. 44, J. Janick, ed. (Hoboken, New Jersey: Wiley Blackwell), p. 121-172. https://doi.org/10.1002/9781119281269.ch3.

Ferrante, A., Trivellini, A., Scuderi, D., Romano, D., and Vernieri, P. (2015). Post-production physiology and handling of ornamental potted plants. Postharvest Biol. Technol. 100, 99-108.

Fusch, P.I., and Ness, L.R. (2015). Are we there yet? Data saturation in qualitative research. Qual. Rep. 9, 1408-1416. https://doi. org/10.1016/j.postharvbio.2014.09.005.

Gabriel, A., and Menrad, K. (2013). Segmentation of customers of horticultural non-food products in Southern Germany. Ger. J. Agr. Econ. 62, 192-202.

Getter, K.L., Behe, B.K., and Wollaeger, H.M. (2016). Comparative consumer perspectives on eco-friendly and insect management practices on floriculture crops. HortTechnology 26, 46-53. https:// doi.org/10.21273/HORTTECH.26.1.46.

Hall, C.R. (2011). Making cents of green industry economics. HortTechnology 20, 832-835. https://doi.org/10.21273/ HORTTECH.20.5.832.

Hall, C.R., and Hodges, A.W. (2011). Economic, environmental and well-being benefits of lifestyle horticulture. Chron. Hortic. 51, 5-8.

Hobbs, J.E., and Young, L.M. (2000). Closer vertical co-ordination in agri-food supply chains: A conceptual framework and some preliminary evidence. Int. J. Supply Chain Manag. 5, 131-143. https://doi.org/10.1108/13598540010338884.

Kaplinsky, R., and Morris, M. (2000). A Handbook for Value Chain Research (Sussex: University of Sussex).

Kerr, J.T. (2017). A cocktail of poisons. Science 356, 1331-1332. https://doi.org/10.1126/science.aan6173. 
Kishi-Kaboshi, M., Aida, R., and Sasaki, K. (2017). Generation of gene-edited Chrysanthemum morifolium using multicopy transgenes as targets and markers. Plant Cell Physiol. 58, 216-226. https://doi. org/10.1093/pcp/pcw222.

Krause, H., Lippe, R.S., and Grote, U. (2015). Value chain analysis of potted Phalaenopsis: A case study from the Netherlands and Germany. In Aktuelle Forschung in der Gartenbauökonomie, W. Dirksmeyer, L. Theuvsen, and M. Kayser, eds. (Braunschweig, Germany: Thünen-Institut), p. 215-230.

Ludwig-Ohm, S., and Dirksmeyer, W. (2013). Ausgewählte Analysen zu den Rahmenbedingungen und zur Wettbewerbsfähigkeit des Gartenbaus in Deutschland (Braunschweig, Germany: ThünenInstitut).

McDonald, M.B., and Kwong, F.Y. (2005). Flower seeds. Biology and technology (Wallingford: CABI Publ.). https://doi. org/10.1079/9780851999067.0000.

Méndez, A., Paz-Ferreiro, J., Gil, E., and Gascó, G. (2015). The effect of paper sludge and biochar addition on brown peat and coir based growing media properties. Sci. Hortic. 193, 225-230. https://doi. org/10.1016/j.scienta.2015.07.032.

Menrad, K., and Gabriel, A. (2009). National innovation systems in horticulture in Germany and the Netherlands. IJPP 4, 479. https:// doi.org/10.1504/IJPP.2009.025258.

Porter, M.E. (1980). Competitive Strategy. Techniques for Analyzing Industries and Competitors (New York: Free Press).

Porter, M.E. (1985). Competitive Advantage. Creating and Sustaining Superior Performance (New York: Free Press).

Porter, M.E. (1991). Towards a dynamic theory of strategy. Strat Manag. J. 12, 95-117. https://doi.org/10.1002/smj.4250121008.

Porter, M.E. (1998). Competitive Strategy. Techniques for Analyzing Industries and Competitors: With a New Introduction (New York, London: Free Press).

Porter, M.E. (2008). The five competitive forces that shape strategy. Harv. Bus. Rev. 86, 78-93.

Riedel, B., Bokelmann, W., and Canavari, M. (2009). Combining cluster and value chain approaches to analyze the competitiveness of fresh vegetables producers: Case studies in Germany, Italy and Spain. EAAE Seminar 113, 1-17.

Rihn, A., Khachatryan, H., Campbell, B., Hall, C., and Behe, B. (2016). Consumer preferences for organic production methods and origin promotions on ornamental plants. Evidence from eye-tracking experiments. J. Agric. Econ. 47, 599-608. https://doi.org/10.1111/ agec. 12258

Riisgaard, L. (2009). How the market for standards shapes competition in the market for goods. Sustainability standards in the cut flower industry (Copenhagen: DIIS Working Papers).

Schreier, M. (2012). Qualitative Content Analysis in Practice (Los Angeles: Sage).

Schwend, T., Prucker, D., and Mempel, H. (2015). Red light promotes compact growth of sunflowers. Eur. J. Hortic. Sci. 80, 56-61. https:// doi.org/10.17660/eJHS.2015/80.2.2

Secorun, L. (2016). Ethiopia vows to protect European companies after farms attacked. The Guardian. 26 Oct. 2016. https://www. theguardian.com/sustainable-business/2016/oct/26/ethiopiavows-to-protect-european-companies-after-farms-attacked.

Shibata, M. (2008). Importance of genetic transformation in ornamental plant breeding. Plant Biotechnol. J. 25, 3-8. https://doi. org/10.5511/plantbiotechnology.25.3.
Tagliabue, G. (2017). The EU legislation on "GMOs" between nonsense and protectionism: An ongoing Schumpeterian chain of public choices. GM Crops \& Food 8, 57-73. https://doi.org/10.1080/ 21645698.2016 .1270488 .

Van der Vorst, J.G.A.J., Ossevoort, R., De Keizer, M., Van Woensel, T., Verdouw, C.N., Wenink, E., Koppes, R., and Van Willegen, R. (2016). DAVINC3I: Towards collaborative responsive logistics networks in floriculture. In Logistics and Supply Chain Innovation, H. Zijm, M. Klumpp, U. Clausen, and M.T. Hompel, eds. (Heidelberg: Springer), p. 37-53. https://doi.org/10.1007/978-3-319-22288-2_3.

Verdouw, C.N., Beulens, A.J.M., Trienekens, J.H., and Verwaart, T. (2010). Mastering demand and supply uncertainty with combined product and process configuration. Int. J. Comput. Integr. M. 23, 515528. https://doi.org/10.1080/09511921003667706.

Yue, C., Dennis, J.H., Behe, B.K., Hall, C.R., Campbell, B.L., and Lopez, R.G. (2011). Investigating consumer preference for organic, local, or sustainable plants. HortScience 46, 610-615. https://doi. org/10.21273/HORTSCI.46.4.610.

Zhang, B., Yang, X., Yang, C., Li, M., and Guo, Y. (2016). Exploiting the CRISPR/Cas9 system for targeted genome mutagenesis in Petunia. Nature - Sci. Rep. 6, 20315. https://doi.org/10.1038/srep20315.

Zylberberg, E. (2013). Bloom or bust? A global value chain approach to smallholder flower production in Kenya. J. Agribus in Dev. \& Em. Econ. 3, 4-26. https://doi.org/10.1108/20440831311321638.

Received: Mar. 27, 2019

Accepted: Apr. 6, 2020

Addresses of authors:

Nirit Havardi-Burger ${ }^{1, *}$, Heike Mempel ${ }^{2}$ and Vera Bitsch ${ }^{1}$

${ }^{1}$ Technical University of Munich, School of Management and School of Life Sciences Weihenstephan, Chair of Economics of Horticulture and Landscaping, Alte Akademie 16, 85354 Freising, Germany

${ }^{2}$ University of Applied Sciences Weihenstephan-Triesdorf, Department of Horticulture and Food Technology,

Am Staudengarten 10, 85354 Freising, Germany

* Corresponding author;

E-mail: nirit.havardi-burger@tum.de

Tel.: +49 8161 71-2587; Fax: +49 8161 71-2530 